\title{
THE EFFECTIVENESS OF DESCRIBE AND DRAW TECHNIQUE TO IMPROVE STUDENTS WRITING SKILL
}

\section{EFEKTIVITAS TEKNIK 'DESCRIBE AND DRAW' UNTUK MENINGKATKAN KEMAMPUAN MENULIS SISWA}

\author{
Dede Khoirunisa $^{1}$, Juwita Boneka Sinaga, 2 \\ English Education Department University of Riau Kepulauan Batam \\ dedekhoirunisa96@gmail.com ${ }^{l}$-juwitaboneka@gmail.com ${ }^{2}$
}

\begin{abstract}
The objective of the study is to find out whether describe and draw technique is effective in improving student ability in writing at SMKS AL-JABAR Batam this study is limited on Writing for eleventh grade student at SMKS AL-JABAR Batam in Academic year 2018/2019.The study designed used by the researcher is quasi experimental design (pre-test and post-test control group). The population of study is eleventh grade students of SMKS AL-JABAR Batam. They are four classes of eleventh grade student with the total number 71 students. The samples of the study are two classes which consist of 24 student in experiment class and 24 students in control class. The instrument in this study is writing test. The data analyzed using statistical analysis using $t$-test. The result showed that sig (2 tailed) of student pre-test and post-test in experimental was 0.401 and standard significant level it was 0.05 by comparing the sig (2 tailed) and standard significant level, it was known that sig ( 22 tailed 0 was bigger than standard significant. The calculation of testing hypothesis used t-test formula with null hypothesis $(\mathrm{Ho})$ and alternative hypothesis $(\mathrm{Ha})$ it can be sum up that $t_{c}(1.729) \geq t$ table (1.71). Therefore, Ho is rejected and Ha is accepted. The conclusion was Describe and Draw Technique gives significant effect in improving student ability in writing.
\end{abstract}

Keywords: Writing, improving, Describe and Draw Technique

\begin{abstract}
ABSTRAK
Tujuan dari penelitian ini adalah untuk mengetahui apakah Describe and Draw Technique efektif dalam meningkatkan kemampuan siswa dalam menulis di SMKS AL-JABAR Batam. Penelitian ini terbatas pada siswa sebelas di SMKS AL-JABAR Batam pada tahun akademik 2018 /2019. Penelitian yang dirancang oleh peneliti adalah desain eksperimen (pre-test dan post-test control group). Populasi penelitian ini adalah siswa kelas XI SMKS AL-JABAR Batam. Terdapat empat kelas XI dengan total 71 siswa. Sampel penelitian adalah dua kelas yang terdiri dari 24 siswa di kelas eksperimen dan 24 siswa di kelas kontrol. Instrumen dalam penelitian ini adalah tes menulis. Data dianalisis secara statistic, dengan menggunakan uji-t. Hasil penelitian menunjukkan bahwa sig (2 tailed) dari pre-test siswa dan post-test dalam eksperimen adalah 0,401 dan tingkat signifikansi standar adalah 0,05 dengan membandingkan sig (2 tailed) dan tingkat signifikansi standar, diketahui bahwa sig (s2 tailedO lebih besar dari standar signifikan. Perhitungan hipotesis pengujian menggunakan rumus t-test dengan null hipotesis $(\mathrm{Ho})$ dan alternatif hipotesis ( $\mathrm{Ha}$ ) dapat disimpulkan
\end{abstract}


Khoirunisa and Sinaga: The Effectiveness Draw and Describe Technique...

bahwa tc $(1,729) \geq t$ tabel $(1,71)$. Oleh karena itu, Ho ditolak dan Ha diterima. Kesimpulannya adalah Describe and Draw Technique memberikan pengaruh yang signifikan dalam meningkatkan kemampuan siswa dalam menulis.

Kata kunci: Menulis, meningkatkan, describe and draw technique

\section{INTRODUCTION}

Writing is a means of communication when the other person is not right here in front of us. Writing is a process of using symbols (letters of the alphabet, punctuation and spaces) to communicate thoughts and ideas in readable form. For student, this purpose can be provide the opportunity to express themselves through a written form.

On learning English as foreign language, writing is categorized as one of hardest and difficult skill because it requires grammatically accuracy, punctuation, capitalization, spelling, and vocabulary. This study focused on writing skill that should be mastered by students. Writing can be the way in expressing student's idea in written. Brown (2001: 336) claims that writing is a thinking process. Furthermore, he states that writing can be planned and given with an unlimited number of revisions before its release.

When the writer did teaching practice at MKS AL-JABAR Batam at eleventh grade, the writer had given ask in procedure text. However students writing skill still low such as they are have lack of vocabulary and also can't make sentence with correct grammatical and writing can enrich their vocabulary by exercise so they will find new vocabulary when write also learning is often seen as a serious and stressful activity in writing. The writer thought that interesting technique is needed to improve students writing skill and to make the students more interest in teaching and learning process specially in writing skill. They are several techniques in teaching learning writing such as mind mapping technique, flowchart technique, peer feedback technique, exploration technique and modeling technique. Pictures is one of the ways to explain the real situation, it is very simple and that can be picked up from newspaper, magazine, internet, book etc. pictures are extremely useful for a variety of communication activities especially where they are have a game like feel such as, describe and draw activities.

Patel (2008: 125) states that writing is essential features of learning a language because it provides very good means of foxing the vocabulary, spelling, and sentence pattern. Writing help student in progress their ability in practice students' vocabulary, enrich their vocabulary when they make a sentence. It can help student spelling the words that they write and acknowledge them about the sentence pattern. Writing also the act of forming letters or 
Khoirunisa and Sinaga: The Effectiveness Draw and Describe Technique...

combination of letters, making marks none flat surface of some kind. It is more than production of graphic symbols, just as speech is more than the production of sound. The symbols have to be arranged to form sentence.

Brown (2001) states that writing is the most difficult skill for second or foreign language learners to master. The difficulties are not only in generating and organizing ideas, but also in translating these ideas into a readable text. The difficulty becomes more noticeable if their language proficiency is weak.

Granville (2001) states that there are three purpose of writing, to entertain, to inform, and to persuade. And Brown (2003) also states that "the purpose of writing, in principle, is the expression of ideas, the conveying of message to the reader. So the ideas themselves should arguably be seen as the most important aspect in the writing".

In addition, they are really only four common purposes in writing they are: to inform, to explain, to persuade, and to amuse others.

1. Writing to inform

Much of the writing that the writers will do, they will intend simply to inform their readers about a subject. To inform is transmit necessary information about the subject to the readers, and usually this means just telling the readers what the facts are or what happened

2. Writing to explain

Writing to explain means writing to take what is unclear and make it clear. In explanatory writing, a writer who understands a complex topic must take sure that his readers understand it as well. All of us use several common methods of explaining something to another person in our everyday conversation and these same techniques can provide basic strategies for organizing an explanation in writing.

3. Writing to persuade

The most important writing we ever do in our personal life our work life, and may be our school life will probably persuasion complaint to the rent board about our landlord, letters of application jobs, essay on examinations are all likely to involve writing persuasively. Your task in persuasion is to convince your readers to accept the main idea, even though it may be controversial.

4. Writing to Amuse Other

Writing to amuse requires that you focus on readers other than yourself. You may enjoy to the experience and take pride in what you accomplish, but you cannot settle for 
Khoirunisa and Sinaga: The Effectiveness Draw and Describe Technique...

amusing yourself alone. Writing to amuse gives you opportunity to bring pleasure to others. Seize the opportunity and make the most of it.

Process writing as a classroom activity incorporates the four basic writing stages. Those are, planning, drafting (writing), revising (redrafting) and editing and there other stages externally imposed on student by the teacher, namely, responding (sharing), evaluating, and post-writing. The plan learning experiences for students describe:

1. Planning (pre-writing)

Pre-writing can stimulate thoughts for getting started. It moves students away from having to face blank page toward generating tentative ideas and gathering information for writing. The following activities provide the learning experiences for students at this age.

2. Drafting

At the drafting stages, the writer focuses on the fluency of writing and is not preoccupied with grammatical accuracy or the neatness of the draft. The first draft will need to be sorted and strained but it should be more focused than the free-writing.

3. Revising

Revising is to rewrite what the written before. When doing the revision, the writer (students) reworks his draft according to the feedback that was given. They may add some information, which do not exist in writing work. The most important thing is checking the features of writing such as content, purpose, and organization.

4. $\quad$ Editing

Before final draft is evaluated, the students ought to read for their mistake in mechanics.

Editing only pays attention to mechanic elements which include spelling, grammar, punctuation, and capitalization. It is important for students to edit by themselves as they have received feedback before they revise their written product.

Brown (2003: 220) asserts that are four categories of technique for teaching writing. Those four categories are as follows:

1. Imitative Writing

This category includes the ability to spell correctly. The students have to attain skill in the fundamental, basic tasks of writing letters, words, punctuation, and very simple sentence. Elementary school students are in the category of imitative writing.

2. Intensive (controlled) writing

In this category, most assessment tasks are more concerned with a focus on form, and are rather strictly controlled by the text design. Students have to produce appropriate 
Khoirunisa and Sinaga: The Effectiveness Draw and Describe Technique...

vocabulary within a context, collocation, idioms, and correct grammatical features in the level of sentence. This category is applied for junior high school level.

3. Responsive Writing

This level requires the students to perform a limited discourse level. It means that students have to create connected sequence of two or three paragraphs. It focuses on the discourse conventions that will achieve the objectives of the written text. It also emphasizes on context and meaning. This skill area of writing is usually intended for senior high school level.

4. Extensive Writing

Extensive writing implies a successful management of all processes and strategies of writing for all purposes, such as an essay, a term paper, a thesis, etc. The writers focus on achieving a purpose, organizing and developing ideas logically, using details to illustrate ideas, demonstrating syntactic and lexical varieties, and so on. This level is usually for advanced learners.

So sum up, to be able to write well, students have to practice a lot. Practice to reach the next level of writing, teacher should provide them writing exercise with sufficient time. It does not matter how many step they should pass, practicing a lot can make them advance writers.

Teacher should have some requirements in teaching writing. They are facilitator and responden to students (Brown, 2001: 340). As a facilitator, they offer guidance for students to write. As a respondent, they should ensure students, respond to, and use varieties of materials and technique. Material, technique, and media have to be combined in a balance without forgetting the goals. Further, Harmer (2004:340) says that when the teacher asks students to write, the play three roles, i.e. a motivator, a resource, and a feedback provider.

1. Motivator

When the teacher give a writing task, they have to motivate the students, create the right condition of ideas, persuade them to do some activities, and encourage them to make as much effort as possible they can.

2. Resource

The teachers have to ready to supply information and language. When it necessary. They need to offer advice and suggestions in a constructive and tactful way.

3. Feedback provider 
Khoirunisa and Sinaga: The Effectiveness Draw and Describe Technique...

The teacher has to respond positively and encouragingly to the content of students writing. In addition, they need to offer corrections and suggestions based on what students need at a particular level and on the tasks that they have understood.

Based on the theories about the teachers roles teacher control everything that occurs in the classroom. They are a facilitator and motivator for students. They are a resource where the students can get all the information they need. When they make mistakes and errors, they have to be ready to give feedback. Further, the most important thing is he needs to decide what technique should be applied in a certain condition. The technique which is chosen, it should to create enthusiasm and effective teaching learning.

On the teaching of writing, an evaluation should be done to measure or to know the students' ability in writing. The effectiveness of a learning process of writing skill can be measured through an evaluation activity. Brown (2001: 357), stated that categories for evaluating writing are:

1. Content, It includes thesis statement, related ideas, development of ideas, and development of ideas and development of ideas through personal experience, illustration, facts, and opinions.

2. Organization, It includes the effectiveness of introduction, logical sequence of ideas, conclusion and appropriate length.

3. Discourse, It includes topic sentence, paragraph unity, transitions, discourse markers, cohesion, rhetorical conventions, reference, fluency, economy, variation.

4. Syntax, It includes of grammatical structure of sentences, format in words and phrases.

5. Vocabulary, It includes of words or symbols serving as a means of expression

6. Mechanics, It includes spelling, punctuation, and citation of references, neatness and appearance.

Text is explicit not because it says everything all by itself but rather because it strikes a careful balance between what needs to be said and what may be assumed. The writer's problem is not just being explicit; the writer's problem knowing what to be explicit about.

Writing is the last skill that cannot ignore in English learning. When the students write a text, they should not only write semantically correct but also should use correct grammar. Generally, writing is a complex process that involves a range of skills and tasks because by writing process, each of which focuses on specific tasks. Creating a text requires us to make choices about the words they use and how they put them together. If students make the right choices then they can communicate with others. Our choice of words will 
Khoirunisa and Sinaga: The Effectiveness Draw and Describe Technique...

depend on our purpose and our surroundings (context). From the explanation above, the writer would like to carry out a research under the title the effectiveness of describe and draw technique to improve students writing skill at the eleventh grade SMKS AL-JABAR Batam in academic year 2018/2019.

\section{METHODOLOGY}

The kind of this research was quasi experimental research. This research was conducted at SMKS AL-JABAR Batam. This research was conducted in November 2018. This research used two classes as the subject at eleventh grade of SMKS AL-JABAR Batam. The first class (A) treat used Describe and Draw Technique and second, control class (B) traditional method. The data collected from the student by giving instrumentation namely writing test instrument which is focused on writing skill. The instruments consist of two tests, pre-test that collected before applying the technique and post-test which is given after applying the technique.

Sugiono (2012) state that "a hypothesis test is to see whether the research gives an effect or not, whether the research supports or rejected in the process of research".It is same as Best 2006 also stated. After the data were collected by given pre-test and post-test, the data treatment with statistical analysis normality test, homogeneity test and hypothesis test using t-test. The conclusion for hypothesis test is if the value t-obtain is bigger than value of t-table, Ha is accepted. On the contrary, if the value $t$ obtain is equal, smaller than the value t-table, Ho is not accepted.

\section{RESULT AND DISCUSSION}

The summary of result in this experiment shown in Table 1. Based on Table 1, obtained that the pre-test score of experimental class higher than control class. The data from the both of class have normal distribution. However the homogeneity test shows the both of class are homogeny. The similar result obtained for the post-test score, where the data distributed normally and the variance of the data from the both class is homogeny.

Discussion from the analyzed data, the researcher concludes that there is no significant difference between the students' scores in pretest. In this research, the researcher gave treatment to the experimental group for twice by using describe and draw technique. On the other hand, the researcher did not give any treatment to control group as used in experimental group. During the treatment, the researcher only explained about writing as usual. And it makes the students got bored and lost their interest to learn English. And after 
Khoirunisa and Sinaga: The Effectiveness Draw and Describe Technique...

those treatments, both experimental and control are given post-test, the researcher got conclusion that the students who are taught using describe and draw technique got higher score that the students who are taught without using describe and draw technique.

Table 1 Summary data from control and experiment class

\begin{tabular}{lcc}
\hline & Control class & Experimental class \\
\hline Number of samples & 24 & 24 \\
Pre-test score & & \\
$\quad$ Mean & 52.71 & 60.83 \\
$\quad$ Variance & 48.781 & 57.971 \\
$\quad$ Normality test & $\chi_{c}^{2}(3.66)<\chi_{t}^{2}(11.070)$ & $\chi_{c}^{2}(2.33)<\chi_{t}^{2}(11.070)$ \\
$\quad$ Homogeinity test & $\mathrm{F}_{\mathrm{c}}(1.213)<\mathrm{F}_{\mathrm{t}}(1.734)$ & \\
Post test score & 59.38 & 68.33 \\
Mean & 128.940 & 64.493 \\
Variance & $\chi_{c}^{2}(11)<\chi_{t}^{2}(11.070)$ & $\chi_{c}^{2}(6.22)<\chi_{t}^{2}(11.070$ \\
Normality test & $\mathrm{F}_{\mathrm{c}}(0.0019)<\mathrm{F}_{\mathrm{t}}(1.734)$ & \\
Homogeinity test & & \\
\hline
\end{tabular}

The final conditions both of group in this research are known from post-test result. Writer collected the data by using instrument writing test. From the result, it can be concluded that the test scores in experimental class was increase, otherwise the control class did not use Describe and Draw Technique. The analyzing data used $t$-test formula. The data t-test in Writing skill of pre-test experimental and control class performed to determine whether there is a difference in Writing ability between two class. The result calculation shown that $t_{\text {count }}>t_{\text {table }}$ with confident interval $95 \%$ and $\mathrm{df}=22$. Hypothesis analysis for the two classes using t-test obtained $t_{c}=1.729$ and $t_{t}=1.717$ at alpha 0.05 . It indicates that there is significant different between experimental class and control class. From this result we can conclude that describe and draw technique which is used in the experimental class useful to enhance the score of writing skill of the students.

As discussed in the results above and hypothesis testing, the use of describe and draw technique improved students' writing skill. It is because there is improving the test value in both of control and experimental group. Although the two groups' scores are increasing, the score of experimental group is higher than control group. The higher score of experimental group can be reached because the group is taught using describe and draw technique. While in the experimental group, the students are so enthusiastic and pay more attention when the teacher explains the material and when the teacher asks them to write, they did it well. 
Khoirunisa and Sinaga: The Effectiveness Draw and Describe Technique...

Similarly with Dewi(2018) said that the students need more practices in writing is in demand since the goal to make students able to write well in academic.

\section{CONCLUSION AND SUGGESTION}

Based on the research conducted at eleventh grade student of SMKS AL-JABAR Batam, It can be concluded that Describe and Draw Technique gave significant effect on student writing skills. The final finding of this study found that there is a significant difference on the writing result by using the describe and draw technique compare to another method which was given before. Finally, the writer suggests that this finding need to continue to develop the result of this research.

\section{REFFERENCES}

Brown, H. Douglas. 2001. Teaching by Principles an Interactive Approach to Language Pedagogy. Longman.

Brown,H. Douglas. 2003. Prince Brown, Teaching by Principles an Interactive Approach to Language Pedagogy. Longman.

Patel, M. F. 2008. English Language Teaching. New Delhi The Free Press

Dewi, Desi Surlitasari (2018), An Analysis of EFL College Level Learner's writing competence in Writing an Argumentative Essay. Cahaya Pendidikan, Vol. 4 No:23-33Juni 2018ISSN : 1460-4747

Fraenkel, Jack. 1932. The Basic of Educational Research: New York: Mc Graw - Hill ESL/ELT

Granvilee, Kate. 2001. Writing From Start to Finish: A Six Step Guide. Published By Griffin Press, South Australia.

Harmer, Jeremy. 2007. How to Teach Writing. Harlow: Longman

John W.Best, Dkk. 2006. Research in Education. Tenth Edition. Boston : Pearson Educational Inc.

Sugiyono. 2012. Metode Penelitian Kuantitatif Kualitatif dan $R \& D$. Bandung: Alfabeta 